\title{
Thoracotomy versus transhiatal esophageal dissection. Which is the best surgical approach to short esophagus? ${ }^{1}$
}

\author{
Toracotomia ou dissecção esofágica trans-hiatal. Qual a \\ melhor abordagem para o esôfago curto?
}

\author{
Thiago Beduschi', André Vicente Bigolin II, Leandro Totti CavazzolaII \\ ${ }^{1}$ Research performed at Department of Surgery and Experimental Research, Faculty of Medicine, Lutheran University of Brazil (ULBRA), Canoas- \\ RS, Brazil. \\ ${ }^{I} \mathrm{MD}$, Clinical Fellow, Division of Transplantation, Indiana University School of Medicine. United States. Main author. Responsible for conception \\ and procedures. \\ II Graduate student, Faculty of Medicine, ULBRA, Canoas-RS, Brazil. Literature review, interpretation of data and manuscript writing. \\ III PhD, Assistant Professor of Surgery, ULBRA, Canoas-RS, Brazil. Tutor. Responsible for conception, surgical procedures and critical review.
}

\begin{abstract}
Purpose: To evaluate different approaches performed to obtain a more significant esophageal length. Methods: An experimental model using 28 cadavers was conceived. Randomized groups: Group A ( $\mathrm{n}=10)$ underwent laparotomic transhiatal approach; Group B ( $\mathrm{n}=9$ ) which differed from the first in the conduction of a wide phrenotomy and Group $C(n=9)$ esophageal dissection was performed through a left anterolateral thoracotomy. Results: Final length variations for Group A were $2.12 \mathrm{~cm}$ and $3.29 \mathrm{~cm}$ and for Group B $3.24 \mathrm{~cm}$ and $3.66 \mathrm{~cm}$, without and with esophageal traction, respectively. In Group C length gain observed was $3.81 \mathrm{~cm}$. The mediastinal dissections conducted through the hiatus was considered the procedure that produced the better esophageal mobilization, and the association of wide phrenotomy significantly improved the results. Conclusions: The mediastinal dissection was the most effective to improving gain in abdominal esophagus. When toracotomy and laparotomy were compared, no significant differences were observed in the outcome.
\end{abstract}

Key words: Esophagus. Surgical Procedures, Operative. Thoracotomy. Laparotomy. Mediastinum. Dissection. Cadaver.

\section{RESUMO}

Objetivo: Avaliar diferentes procedimentos realizados para obtenção de um ganho mais significativo no comprimento esofágico. Métodos: Um estudo experimental utilizando 28 cadáveres foi realizado. Randomização dos grupos: Grupo A ( $\mathrm{n}=10$ ): Submetido à abordagem laparotômica trans-hiatal; Grupo B $(n=9)$ : Diferente do primeiro apenas pela realização de uma frenotomia ampla; e Grupo C (n=9): A dissecção esofágica foi realizada por uma toracotomia anterior esquerda. Resultados: A variação final do comprimento para o Grupo A foi 2,2 cm e 3,29 cm e para o Grupo B 3,24cm e 2,66cm, medidas na ausência e presença de tração esofágica, respectivamente. No Grupo $\mathrm{C}$ o ganho de comprimento observado foi de $3,81 \mathrm{~cm}$. A dissecção mediastinal conduzida através do hiato foi considerada o procedimento de melhor mobilização esofágica e a associação de uma ampla frenotomia levou a uma significativa melhora nos resultados. Conclusões: A dissecção mediastinal foi a mais efetiva para promover o aumento do esôfago abdominal. Quando comparadas toracotomia e laparotomia, nenhuma diferença significativa foi observada no desfecho do estudo.

Descritores: Esôfago. Procedimentos Cirúrgicos Operatórios. Toracotomia. Laparotomia. Mediastino. Dissecção. Cadaver. 


\section{Introduction}

Gastroesophageal reflux disease (GERD) is a chronic dysfunction often observed in surgical practice'. Among the complications caused by reflux, a condition known as short esophagus is considered the most severe stage, from the anatomical standpoint. The gastric reflux, due to its acid contents, leads to a chronic inflammation that causes the axial contraction of the distal esophagus and consequent reduction in length ${ }^{2}$. This condition was defined by Large as having a transoperative diagnostic nature, and was characterized by esophageal length that is not long enough to afford the permanence of the gastroesophageal junction (GEJ) below the esophageal hiatus, without employing traction ${ }^{3}$.

In spite of the theories proposed to shed new light on the physiopathogenesis of short esophagus, some authors have raised a few doubts about the real existence of this dysfunction. These uncertainties are based on the controversial prevalence of the pathology in several series and on the assumption of the inability of esophageal mobilization ${ }^{4-7}$. Nevertheless, the absence or reduction of abdominal esophagus length may trigger the failure of anti-reflux surgery because of the migration of the new valve to the thorax. This situation can be overlooked during the surgery due to maintenance of the esophagus in abdomen cavity following traction. Surgical techniques have been described based on esophageal dissection or even on the conduction of gastroplasty, with the aim to maintaining GEJ at a distance of more than $2.5 \mathrm{~cm}$ beyond the esophageal hiatus ${ }^{8,9}$. This is an acceptable length to guarantee the abdominal permanence of the anti-reflux valve and its function.

The present study was designed to compare different esophageal dissection techniques. Aiming to find the difference between the approaches as regards the gain in esophageal abdominal length.

\section{Methods}

The present study was based on dissections conducted in fresh human cadavers kept in the Municipal Morgue of the City of Porto Alegre, RS, Brazil. This study was approved by the Committee for Ethics in Research, Lutheran University of Brazil (ULBRA) and authorized by the Department of Teaching and Research of the Municipal Morgue of the City of Porto Alegre.

Twenty-eight cadavers were dissected. Necropsy was conducted and those cadavers that did not present any morphological change in the GEJ and adjacent structures were randomized to form three groups.
Group A: Underwent laparotomic access to the esophageal dissection that was performed through the hiatus.

Group B: Underwent laparotomic access and dissection through the hiatus, similarly to Group A, but followed by a wide phrenotomy. thoracotomy.

Group C: Underwent esophageal dissections by

\section{Description of surgical procedures}

Upon necropsy, cadavers underwent a standard mentopubic incision to establish the cause of death. At this point the samples were evaluated to establish the anatomic normality of GEJ and adjacent structures (Figure 1).

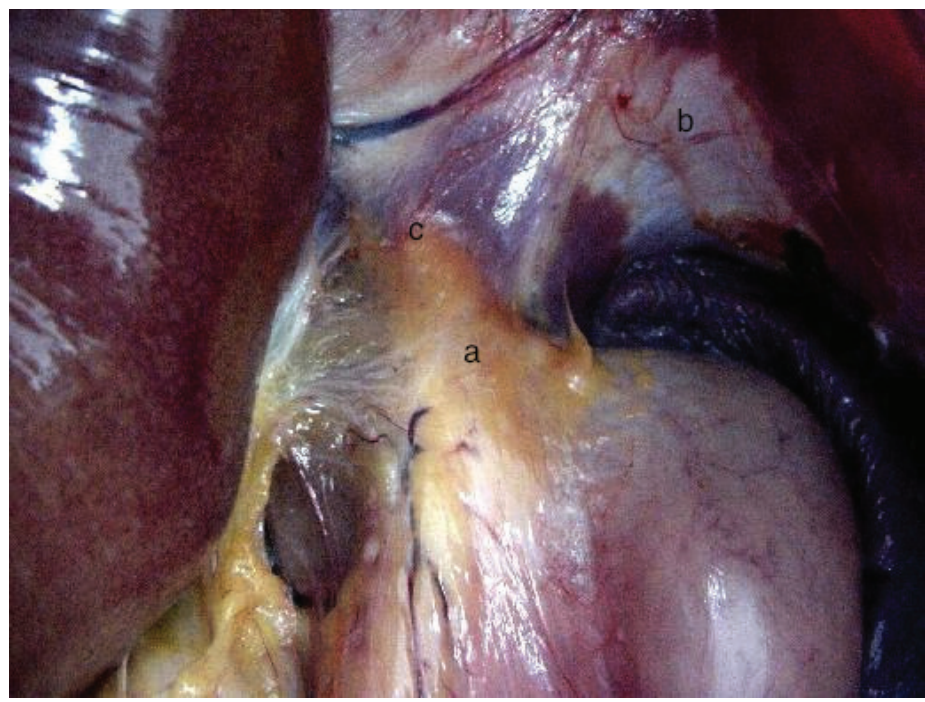

FIGURE 1 - Conserved and usually seen GEJ (a), diaphragm (b) and esophageal hiatus (c).

Only cadavers that were considered free of any anatomical abnormalities in the region were randomized.

The first steps of the dissection procedure were identical for Groups A and B. After spatial orientation in abdominal cavity the dynamometer was placed in the large gastric curvature observing the position that afforded the best traction condition. The next step was the identification of the terminal esophagus and the GEJ.

In order to characterize the GEJ, the anatomical definition used considered the junction of the terminal esophagus and the gastric pouch, also defined as the line across the Hiss angle forming a $90^{\circ}$ angle in relation to the abdominal esophagus. Once this site was defined, one marker stitch was performed and used as landmark of terminal esophagus and reference to carry out the measurements. The purpose of this marker stitch was to maintain 
the exact reference point for measurements when tension is applied to the esophagus. The landmark for abdominal esophagus was the point on the esophagus lying right under or next to the most anterior region of the right diaphragmatic pillar.

After the procedures described above, the first measurements were carried out, that is, the baseline esophageal measurement with and without traction. All groups underwent two types of measurement: the first was without any traction and the second employed a 1-kgf traction defined by a precision dynamometer placed on the large gastric curvature so as to be aligned to the esophagus. Next, the complete dissection and exposure of diaphragmatic pillars was conducted, specially of the right pillar, by means of the opening of the hepatoduodenal and hepatogastric ligaments, side by side with the release of the gastric end of the diaphragm. This dissection approach was called dissection Type 1, a standard for fundoplication (Figure 2).

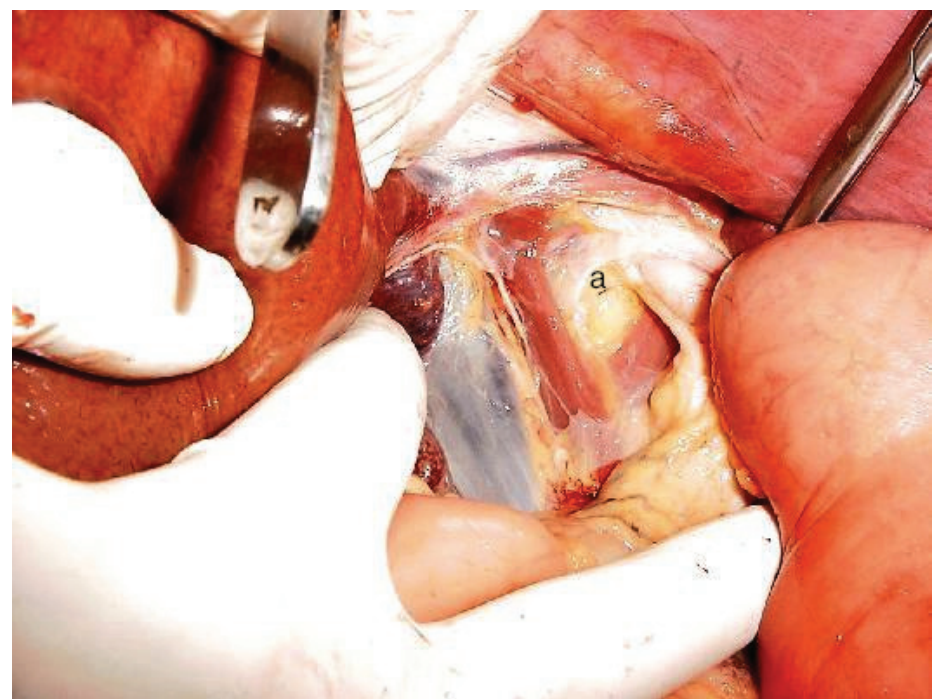

FIGURE 2 - Complete exposure of the esophageal hiatus (a) during dissection Type 1 .

At this step, care was taken to preserve the hepatic branch of the vagus nerve. Also, the peritoneum and the phrenoesophageal membrane were lifted, thus mobilizing the esophagus in the posterior mediastinum and keeping the baseline morphology of the esophageal hiatus. The anterior vagus nerve branch was dissected from the esophageal body and repaired (Figure 3).

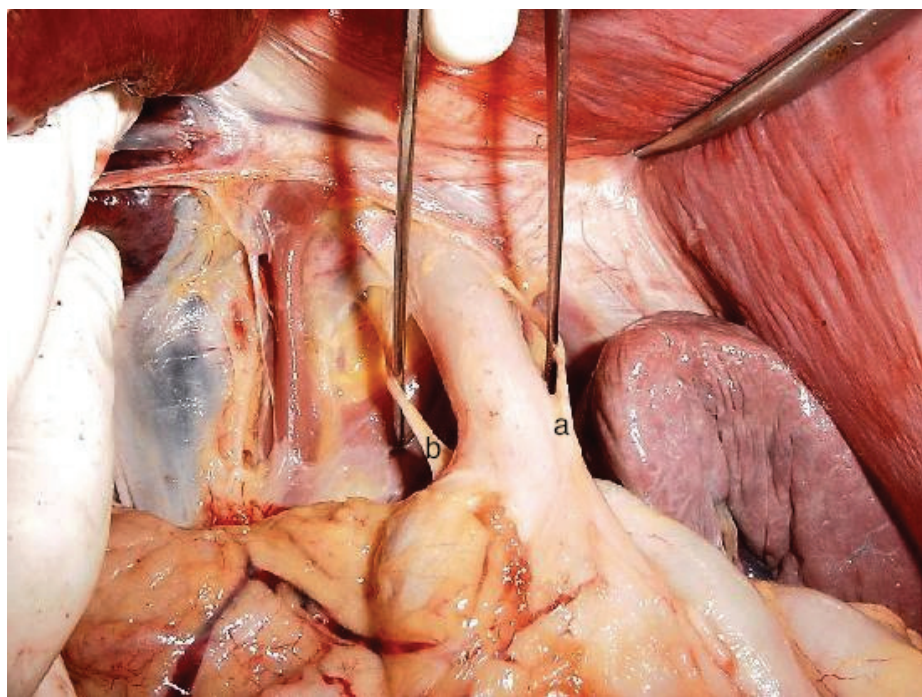

FIGURE 3 - Anterior (a) and posterior (b) vagus nerve branches dissected from the esophageal body before vagotomy.

New measurements were made and after this step, the dissection procedure were different in Group A and B.

The next step was Type 2 dissection, which included a large mediastinal dissection. The esophagus was released by blunt dissection, taking care to preserve pleural integrity. Group A underwent dissection Type 2, observing the conservation of the esophageal hiatus. Group B underwent wide phrenotomy to enlarge the access to the thoracic esophagus. In this group, the last measurements were made after the closing of the diaphragm to reestablish the baseline morphology of the esophageal hiatus and restore the reference point of the proximal abdominal esophagus (Figure 4).

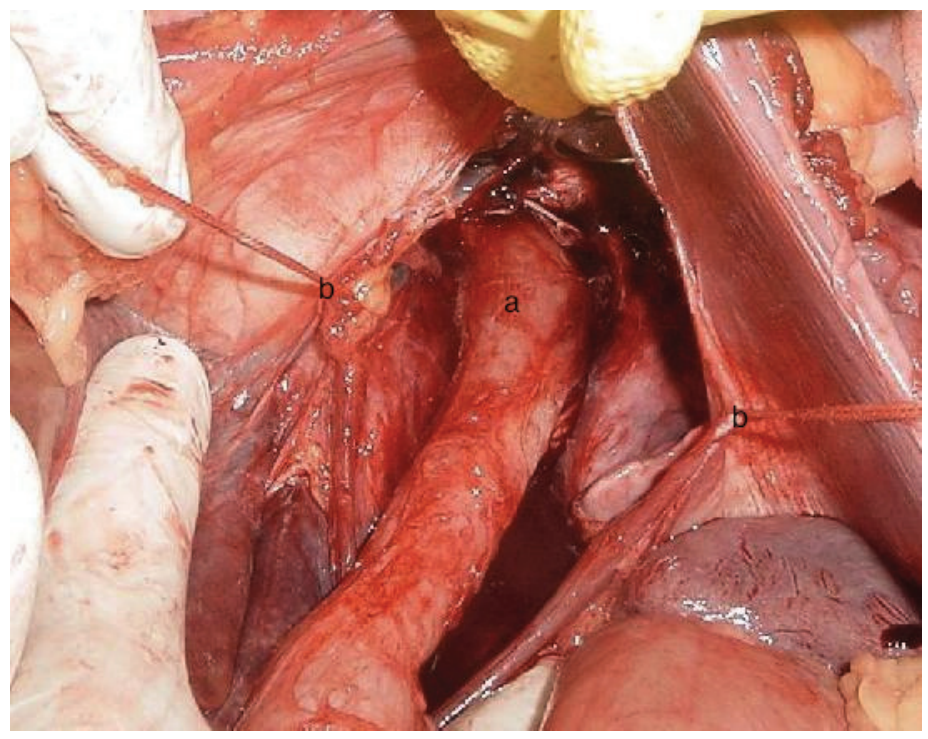

FIGURE 4 - Model of Group B, showing the esophagus (a) dissected in the posterior mediastinum after large phrenotomy. The repair stitches (b) observed were made to restore the baseline morphology of the hiatus, after dissection and perform the measurements. 
In Group $\mathrm{C}$ the mediastinal esophagal dissection was released exclusively by left anterolateral thoracotomy. All measurements were conducted in the abdominal pathway. The access was made possible across the left hemithorax through the pleura. After the initial procedures and measurements, the thoracic esophagus was released from the mediastinal structures upon reaching the aortic arch and left main bronchus. On the pleural side of the diaphragm, the phrenoesophageal membrane was released. After the total dissection of the esophagus, new measurements were made in the abdomen with and without the application of $1-\mathrm{kgf}$ traction. Next step was the performance of an anterior vagotomy, followed by the transection of the posterior vagus nerve. Each procedure was followed by new measurements. A precision caliper was used to conduct the measurements. Dissections were made by at least two people, and one same person was responsible for dissection and measurement procedures, in the same cadaver. Photos were made in itch measurements an a third technician not linked with the study and ignorant in front of the objectives confirmed them.

\section{Statistical analysis}

The data obtained was analyzed using the SPSS program version 10.0. The statistical test used was the ANOVA for independent samples, with significance level of $5 \%$.

\section{Results}

Twenty-eight cadavers (24 males and four females) were dissected, 10 in Group A, 9 in Group B, and 9 in Group C. Mean age of subjects was 40 years, and varied between 16 and 72 years. Nineteen cadavers were of Caucasian origin, while nine were of African-American origin. Mean weight was $65.2 \mathrm{~kg}$ and mean height $1.68 \mathrm{~m}$. No statistical difference was observed between cadavers concerning demographic aspects (Table 1).

TABLE 1 - Demographic aspects.

\begin{tabular}{ccccc} 
& Group A & Group B & Group C & $\boldsymbol{p}$ \\
\hline Age (years) & 44.2 & 36 & 39 & NS \\
Sex (Male/Female) & $9 \mathrm{M} / 1 \mathrm{~F}$ & $7 \mathrm{M} / \mathrm{e} 2 \mathrm{~F}$ & $8 \mathrm{M} / 1 \mathrm{~F}$ & $\mathrm{NS}$ \\
Weight (Kg) & 69.6 & 60.8 & 64.7 & $\mathrm{NS}$ \\
Height (m) & 1.68 & 1.67 & 1.69 & $\mathrm{NS}$ \\
\hline
\end{tabular}

NS: Not significant
The data obtained reveal a pronounced gain in esophageal length in cadavers of Group C $(3.81 \mathrm{~cm}$ without and $3.85 \mathrm{~cm}$ with traction). The dissections executed in Group B came next in efficacy, with mean esophageal length gain of 3.24 and $3.66 \mathrm{~cm}$ without and with traction, respectively. Mean length gain in Group A was only $2.12 \mathrm{~cm}$ without traction and $3.29 \mathrm{~cm}$ with traction. These results show a significant variation in Groups B and C, as compared to Group A. Yet, this difference was not statistically significant when only Groups B and C were compared. The measurements of esophageal length gain are shown in Tables 2, 3 and 4 for Groups A, B and C, respectively.

TABLE 2 - Esophageal length gain in cadavers from Group A in accordance to the stages dissections.

\begin{tabular}{cccccc} 
Group A & $\begin{array}{c}\text { Without } \\
\text { traction } \\
(\mathbf{c m})\end{array}$ & $\begin{array}{c}\text { With } \\
\text { traction } \\
(\mathbf{c m})\end{array}$ & $\begin{array}{c}\text { Median } \\
\mathbf{( c m )}\end{array}$ & SD & $\begin{array}{c}\text { Isolated } \\
\text { structure }\end{array}$ \\
\hline $\begin{array}{c}\text { Baseline } \\
\text { measurement }\end{array}$ & 1.33 & 1.85 & $1.25 / 1.75$ & $0.33 / 0.4$ & - \\
Type 1 & 2.1 & 2.91 & $2.00 / 2.65$ & $0.45 / 0.93$ & $0.77 / 1.06$ \\
Type 2 & 3.45 & 5.14 & $3.4 / 5.00$ & $0.29 / 0.94$ & $1.35 / 2.23$ \\
\hline $\begin{array}{c}\text { Final } \\
\text { variation }\end{array}$ & 2.12 & 3.29 & $2.15 / 3.25$ & & - \\
\hline
\end{tabular}

TABLE 3 - Esophageal length gain in cadavers from Group B in accordance to the stages dissections.

\begin{tabular}{cccccc} 
Group B & $\begin{array}{c}\text { Without } \\
\text { traction } \\
(\mathbf{c m})\end{array}$ & $\begin{array}{c}\text { With } \\
\text { traction } \\
(\mathbf{c m})\end{array}$ & $\begin{array}{c}\text { Median } \\
\mathbf{( c m )}\end{array}$ & SD & $\begin{array}{c}\text { Isolated } \\
\text { structure }\end{array}$ \\
\hline $\begin{array}{c}\text { Baseline } \\
\text { measurement }\end{array}$ & 2.8 & 4.11 & $2.7 / 3.7$ & $0.3 / 1.1$ & - \\
Type 1 & 3.68 & 5.12 & $3.75 / 4.9$ & $0.18 / 0.39$ & $0.88 / 1.01$ \\
Type 2 & 6.04 & 7.77 & $5.8 / 8.2$ & $0.7 / 1.02$ & $2.36 / 2.65$ \\
\hline $\begin{array}{c}\text { Final } \\
\text { variation }\end{array}$ & 3.24 & 3.66 & $3.0 / 3.5$ & $0.58 / 0.62$ & - \\
\hline
\end{tabular}

TABLE 4 - Esophageal length gain in cadavers from Group $\mathrm{C}$ in accordance to the stages dissections.

\begin{tabular}{cccccc} 
Group C & $\begin{array}{c}\text { Without } \\
\text { traction } \\
(\mathbf{c m})\end{array}$ & $\begin{array}{c}\text { With } \\
\text { traction } \\
\mathbf{( c m )}\end{array}$ & $\begin{array}{c}\text { Median } \\
\mathbf{( c m )}\end{array}$ & SD & $\begin{array}{c}\text { Isolated } \\
\text { structure }\end{array}$ \\
\hline $\begin{array}{c}\text { Baseline } \\
\text { measurement }\end{array}$ & 2,37 & 3,41 & $2,5 / 3,5$ & $0,32 / 0,49$ & \\
$\begin{array}{c}\text { Aortic arch } \\
\begin{array}{c}\text { Anterior } \\
\text { Vagotomy }\end{array}\end{array}$ & 5,08 & 5,06 & $4,0 / 5,1$ & $0,44 / 0,56$ & $1,71 / 1,65$ \\
$\begin{array}{c}\text { Posterior } \\
\text { Vagotomy }\end{array}$ & 6,18 & 7,26 & $6,0 / 7,4$ & $1,12 / 1,25$ & $0,97 / 0,96$ \\
$\begin{array}{c}\text { Final } \\
\text { measurement }\end{array}$ & 6,18 & 7,26 & $6,0 / 7,4$ & $1,12 / 1,25$ & \\
\hline $\begin{array}{c}\text { Final } \\
\text { variation }\end{array}$ & 3,81 & 3,85 & $3,8 / 3,6$ & $1,04 / 1,3$ & \\
\hline
\end{tabular}


In the "Median", "SD" and "isolated structure" columns, the value before the slash represents the length obtained without traction, whereas the value following the slash is that obtained with 1-kgf traction. Table 5 shows the baseline measurements and the final variation in esophageal length gain for each group.

TABLE 5 - Comparison between groups.

\begin{tabular}{ccccc} 
& $\begin{array}{c}\text { Group A } \\
(\mathbf{c m})\end{array}$ & $\begin{array}{c}\text { Group B } \\
(\mathbf{c m})\end{array}$ & $\begin{array}{c}\text { Group C } \\
(\mathbf{c m})\end{array}$ & $\boldsymbol{P}$ \\
\hline $\begin{array}{c}\text { Baseline } \\
\text { measurement }\end{array}$ & 1.33 & 2.8 & 2.41 & NS \\
$\begin{array}{c}\text { Final } \\
\text { variation }\end{array}$ & 2.12 & 3.24 & 3.81 & 0.0001 \\
\hline
\end{tabular}

NS: Not significant.

\section{Discussion}

The surgical treatment of GERD is preferentially conducted using the videolaparoscopic technique. Independently of the choice of antireflux procedure, it is essential that the GEJ remain below the diaphragmatic hiatus. Therefore, the transoperative diagnosis of short esophagus requires a change in surgery plans, because the thorax migration of the valve is certain to happen when it has been configured in an esophagus without adequate abdominal length or maintained in the abdomen with considerable traction ${ }^{10-12}$. This condition is mentioned as one of the major causes of failure in antireflux surgeries ${ }^{13-15}$. The occurrence of short esophagus remains controversial, as well as its preoperative diagnosis. This makes it more difficult to choose, in the operation room, the most appropriate approach for surgical correction of short esophagus that will allow a safe anti-reflux procedure $^{16}$.

Collis gastroplasty is a surgical alternative to treat short esophagus that has gained much popularity both through the laparoscopic and laparotomic pathways. It consists in increasing the length of abdominal esophagus by a gastroplasty performed in parallel to the esophageal axis. Yet, the technique has been the object of some criticisms, as the permanence of parietal cells that secrete acid in the neoesophagus, side by side with the lack of motility caused by the stiff row of staplers, allows the direct contact between acidity and the esophageal mucosa. This complication was revealed in some series by measuring postoperative esophageal $\mathrm{pH}^{2,17}$. In spite of that, gastroplasty and fundoplication may be effective in keeping fairly effective control over the reflux symptoms and diminish the chances of recurrence ${ }^{18,19}$. The other surgical options were analyzed in the present study.

The transhiatal esophageal dissection, here called dissection Type 2, has proved to lead to good results ${ }^{20,21}$. Bochkarev et al. ${ }^{21}$ successfully increased esophageal length using the transhiatal laparoscopic dissection in 106 patients, in which no gastroplasty was required. The results of the present study demonstrate an important increase in abdominal esophageal length in both groups that underwent the transhiatal laparotomic pathway, while dissection Type 2 was the best technique in terms of increasing abdominal esophageal length. Herbella et al. ${ }^{22}$ obtained similar results for the increase in esophageal length performing dissections both through the thoracic pathway and transhiatal pathway, without phrenotomy. Our results were above the mean length obtained in that study, which reveals a likely variation in esophageal mobilization, depending on the technique adopted by each individual surgeon. The wide phrenotomy defended by Pinotti seems to be of great importance in the conduction of mediastinal dissection, affording an increase in length in excess of $1 \mathrm{~cm}$ as compared to the group that was not treated with diaphragmatic opening ${ }^{23}$. This difference, apart from being statistically significant ( $p=0.007$ ), may be the main aspect that defines success or failure of the construction of the most appropriate antireflux valve. Also, it led to a very similar result when dissection was conducted through the thorax (Group B, $3.24 \mathrm{~cm}$; Group C, $3.81 \mathrm{~cm}$ ). These results pointed that frenotomy, despite is a non routine procedure, can be an alternative approach without the need of an addictional access when, during a laparotomic approach, were identified that the antireflux valve aren't able to stay in abdominal site.

Recent reports showed that vagotomy can be added as an additional procedure to improve esophagus length. Arkadopoulos et $a l .{ }^{24}$ described a trans-hiatal technique of esophageal mobilization with bilateral vagus resection at 3 different points and obtain $3,7 \mathrm{~cm}$ of gain in esophageal length. The number of vagal transections were directly associated with length gain $(1 \mathrm{~cm}$ per vagus section) and proportionate a satisfactory outcome. In Table 4 is possible observe that abdominal esophageal length increase $1,12 \mathrm{~cm}$ and $0,97 \mathrm{~cm}$ after anterior and posterior vagotomy respectively in our series. This approach is not totally accepted by surgeons. Some patients who undergo peptic ulcer surgery experience disorders in gastric motility, what usually require an additional drainage procedure. The role of this procedure in the treatment of short esophagus was evaluated in a prospective study and does not lead to a higher rate of delayed gastric emptying and other possible side effects ${ }^{25}$.

The present study did not use endoscopic nor laparoscopic methods, though the laparotomic approach follows the principles 
of state-of-the-art surgery. The fact that this study was conducted in cadavers does not lead to inaccuracy nor disqualifies the results obtained, since cadavers are utilized as models for esophageal surgery with excellent results. Apart from this, the relaxation in the diaphragm observed post mortem is similar to that seen in patients under surgical anesthesia ${ }^{26}$. The abdominal measurements conducted in the present study were feasible due to the model used, as in vivo the absence of an abdominal element in surgery conducted through thoracotomy would make such measurements impossible.

\section{Conclusions}

The analysis shows that the transhiatal approach with the assistance of wide frenotomy was similar to the thoracotomy approach when operating the esophagus to ensure an adequate esophageal length. The transhiatal approach has the advantage of being conducted only through an abdominal access, allowing the use of laparoscopy or laparotomy. Vagotomy is an additional procedure and should be considered when esophageal mobilization fails after abdominal and mediastinal dissection.

\section{References}

1. Chinzon D, Rossini ARA, Kiburd B, Navarro-Rodrigues T, Barbuti RC, Hashimoto CL, Eisig JN, Moraes-Filho JPP. Refluxo gastroesofágico diagnóstico e tratamento. Rev AMRIGS. 2006;50 (3):251-63.

2. Jobe BA, Horvath KD, Swanstrom LL. Postoperative function following laparoscopic collis gastroplasty for shortened esophagus. Arch Surg. 1998;133:867-74.

3. Large AM. The problem of short oesophagus with oesophagitis. $\mathrm{Br}$ J Surg. 1962;49:527-32.

4. Madan AK, Frantzides CT, Patsavas KL. The myth of the short esophagus. Surg Endosc. 2004;18(1):31-4.

5. Hill LD, Gelfand M, Bauermeister D. Simplified management of reflux esophagitis with stricture. Ann Surg. 1970;172(4):638-51.

6. Pearson FG, Todd TR. Gastroplasty and fundoplication for complex reflux problems: long term results. Ann Surg. 1987;206:473-81.

7. Lam CR, Gahagan TH. The myth of the short esophagus. In: Nyhus LM, Harkins HN, eds. Hernia. Philadelphia: JB Lippincott; 1964. p.450.

8. Hovarth KD, Swanstrom LL, Jobe BA. The short esophagus: pathofisiology, incidence, presentation and treatment in the era of laparoscopic antireflux surgery. Ann Surg. 2000;232:630-40.

9. Gastal OL, Hagen JA, Peters JH, Campos GM, Hashemi M, Theisen J, Bremner CG, DeMeester TR. Short esophagus: analysis of predictors and clinical implications. Arch Surg. 1999;134(6)633-6; discussion 637-8

10. Awad ZT, Filipi CJ. The short esophagus: pathogenesis, diagnosis and current surgical options. Arch Surg. 2001;136:113-4.

11. Awad ZT, Anderson PI, Sato K, Roth TA, Gerhardt J, Filipi CJ. Laparoscopic reoperative antireflux surgery. Surg Endosc. 2001;15:1401-7.

12. Bataille D, Simoens C, Mendes da CP. Laparoscopic revision for failed anti-reflux surgery. Preliminary results. Hepatogastroenterology. 2006;53:86-8.

13. DePaula AL, Hashiba K, Bafutto M, Machado CA. Laparoscopic reoperations after failed and complicated antireflux operations. Surg Endosc. 1995;9:681-6.

14. Ellis FH Jr, Gibb SP, Heatley GJ. Reoperation after failed antireflex surgery. Review of 101 cases. Eur J Cardiothorac Surg. 1996;10:225-31.

15. Tsuboi K, Omura N, Kashiwagi H, Yano F, Ishibashi Y, Suzuki Y, Kawasaki N, Mitsumori N, Urashima M, Yanaga K. Laparoscopic Collis gastroplasty and Nissen fundoplication for reflux esophagitis with shortened esophagus in Japanese patients. Surg Laparosc Endosc Percutan Tech. 2006;16:401-5.

16. Mittal SK, Awad ZT, Tasset M, Filipi CJ, Dickason TJ, Shinno Y, Marsh RE, Tomonaga TJ, Lerner C. The preoperative predictability of the short esophagus in patients with stricture or paraesophageal hernia. Surg Endosc. 2000;14:464-8.

17. Martin CJ, Cox MR, Cade RJ. Collis-Nissen gastroplasty fundoplication for complicated gastro-oesophageal reflux disease. Aust N Z J Surg. 1995;62:126-9.

18. Peirre AF, Luketich JD, Fernando HC, Christie NA, Buenaventura PO, Litle VR, Schauer PR. Results of laparoscopic repair of giant paraesophageal hernias: 200 consecutive patients. Ann Thorac Surg. 2002;74(6):1909-15; discussion 1915-6.

19. Lin E, Swaford V, Chadalavada R, Ramshaw BJ, Smith CD Disparity between symptomatic and physiologic outcomes following esophageal lengthening procedures for antireflux surgery. J Gastrointest Surg. 2004;8:31-9.

20. O'Rourke RW, Khajanchee YS, Urbach DR, Lee NN, Lockhart B, Hansen PD, Swanstrom LL. Extended transmediastinal dissection: an alternative to gastroplasty for short esophagus. Arch Surg. 2003;138(7):735-40.

21. Bochkarev V, Kwon Lee Y, Vitamvas M, Oleynikov D. Short esophagus: how much length can we get? Surg Endosc. 2008;22:2123-7.

22. Herbella FA, Del Grande JC, Colleoni R. Short esophagus or bad dissected esophagus? An experimental cadaveric study. J Gastrointest Surg. 2003;7:721-5.

23. Pinotti HW. Extrapleural approach to the esophagus through frenolaparatomy. Rev Assoc Med Bras. 1976;22(2):57-60.

24. Arkadopoulos N, Marinis A, Dafnios N, Theodosopoulos T, Smyrniotis V. A novel technique for gaining extra length of the abdominal esophagus. Am J Surg. 2009;198(1):e10-2.

25. Oelschlager BK, Yamamoto K, Woltman T, Pellegrini C. Vagotomy during hiatal hernia repair: a benign esophageal lengthening procedure. J Gastrointest Surg. 2008;12(7):1155-62.

26. Herbella FA, Del Grande JC. Human cadaveres as an experimental model for esophageal surgery. Dis Esophagus. 2001;14:218-22.

\section{Correspondence:}

Leandro Totti Cavazzola

Av. Montenegro, 163/802

90460-160 Porto Alegre - RS Brasil

Phone/Fax: (55 51)9962-5522

cavazzola@gmail.com 